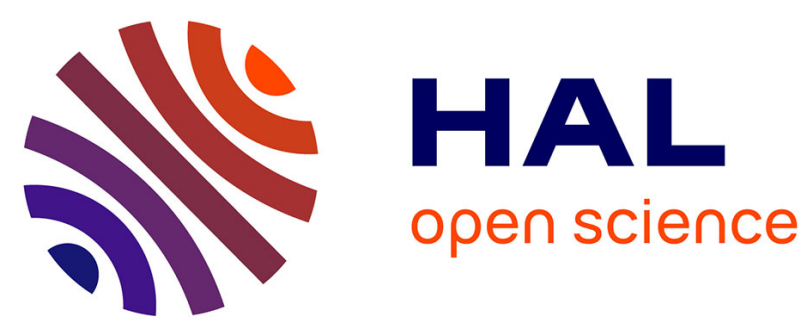

\title{
Direct DNA interaction and genotoxic impact of three metals: Cadmium, nickel and aluminum
}

Catherine Belliardo, Carole Di Giorgio, Florence Chaspoul, Philippe Gallice, David Bergé-Lefranc

\section{- To cite this version:}

Catherine Belliardo, Carole Di Giorgio, Florence Chaspoul, Philippe Gallice, David Bergé-Lefranc. Direct DNA interaction and genotoxic impact of three metals: Cadmium, nickel and aluminum. Journal of Chemical Thermodynamics, 2018, 125, pp.271-277. 10.1016/j.jct.2018.05.028 . hal-02094896

\section{HAL Id: hal-02094896 \\ https://hal-amu.archives-ouvertes.fr/hal-02094896}

Submitted on 10 Apr 2019

HAL is a multi-disciplinary open access archive for the deposit and dissemination of scientific research documents, whether they are published or not. The documents may come from teaching and research institutions in France or abroad, or from public or private research centers.
L'archive ouverte pluridisciplinaire HAL, est destinée au dépôt et à la diffusion de documents scientifiques de niveau recherche, publiés ou non, émanant des établissements d'enseignement et de recherche français ou étrangers, des laboratoires publics ou privés. 
Journal of Chemical Thermodynamics

Elsevier Editorial System(tm) for The Manuscript Draft

Manuscript Number: JCT-17-892

Title: Direct DNA interaction and genotoxic impact of three metals: cadmium, nickel and aluminum

Article Type: Full Length Article

Keywords: aluminum; cadmium; nickel; isothermal titration calorimetry; genotoxicity; DNA binding

Corresponding Author: Dr. Catherine Belliardo,

Corresponding Author's Institution:

First Author: Catherine Belliardo

Order of Authors: Catherine Belliardo; Carole Di Giorgio; Florence Chaspoul; Philippe Gallice; David Bergé-Lefranc

Abstract: This study simultaneously investigates direct DNA interaction and genotoxic impact of three typical metals: aluminum, cadmium and nickel, which the high concentration in soils and which the industries use, result in a daily significant exposure to humans. The three of them are suspected to be involved in carcinogenesis which implies genomic lesions. We propose to first study their genotoxic impact in vivo on primary normal human dermal fibroblast (NHDF) cells with comet assay at pH 7 to measure DNA breaks occurrence. Then, to characterize the metal/DNA interaction by isothermal titration calorimetry (ITC) . Comet assay shows that $\mathrm{Cd}$ and $\mathrm{Ni}$ are genotoxic, they are responsible for DNA breaks starting from 1.10-4 mol.L-1 and 5.10-2 mol.L-1, respectively whereas Al has no effect (on DNA at pH7) as studied by ITC at pH 7 . Cd and $\mathrm{Ni}$ present an electrostatic interaction with DNA phosphate groups. At high Cd concentration, a DNA condensation is observed by contrast. Al has no interaction with DNA phosphate groups, but at pH 4 the electrostatic interaction is strong and the same DNA condensation phenomenon is observed. Metal genotoxic effect seems linked to the electrostatic interaction on DNA phosphate groups. Genotoxic power evolves in parallel to DNA phosphate interaction strength as $\mathrm{Cd}>\mathrm{Ni}>\mathrm{Al}$. If this study shows that metals do not directly break DNA, this binding could be a preferential site for damage due to reactive oxygen species. 
Dear Editor,

Please find herewith an original article exclusively submitted to Journal of Chemical Thermodynamics entitled "Direct DNA interaction and genotoxic impact of three metals: cadmium, nickel and aluminum". This article is complementary of a previous work published in Journal of Thermal Analysis and Calorimetry under the title "Effect of $\mathrm{Ni}(\mathrm{II}), \mathrm{Cd}(\mathrm{II})$ and $\mathrm{Al}(\mathrm{III})$ on human fibroblast bioenergetics, a preliminary comparative study".

The authors and I feel that this work merits publication as an article as it is the first time that the interaction between $\mathrm{Cd}^{2+}, \mathrm{Ni}^{2+}$ and $\mathrm{Al}^{3+}$ with DNA is directly studied using a "non classic" model. This original thermodynamic study allows a fine approach of the mechanisms involved at the molecular level during binding of the metals on the DNA. Moreover, this study compares the thermodynamics of the interaction to the DNA damages observed by comet assay on living cells. In addition, this article emphasizes the contribution of the thermodynamics in the study of toxicology and environmental health.

The authors and I believe that the results of this study could usefully improve the comprehension of metal cations toxicity and could explain medical observations which remain not clearly understood at this time.

Please feel free to contact me for additional information.

Sincerely yours.

Dr. David Bergé-Lefranc 
Highlights

- Nickel, cadmium and aluminum are ubiquitous metals known to induce human diseases.

- Anti-cooperative interaction between $\mathrm{Cd}^{2+}, \mathrm{Ni}^{2+}$ and $\mathrm{Al}^{3+}$ with DNA

- In physiological conditions, cadmium and nickel present an electrostatic interaction with DNA phosphate groups whereas aluminum does not.

- Metal genotoxicity grows concomitantly to the intensity of the interaction with DNA phosphate groups. 
Direct DNA interaction and genotoxic impact of three metals: cadmium, nickel and aluminum

\author{
Catherine Belliardo, Carole Di Giorgio, Florence Chaspoul, Philippe Gallice, David Bergé- \\ Lefranc \\ Institut Méditerranéen de Biodiversité et d'Ecologie marine et continentale (IMBE), Aix-Marseille Université, \\ UMR CNRS IRD Avignon Université, Campus Timone - Faculté de Pharmacie, 27, boulevard Jean-Moulin, F- \\ 13385 Marseille cedex 05, France; email : david.berge-lefranc@univ-amu.fr
}

\begin{abstract}
This study simultaneously investigates direct DNA interaction and genotoxic impact of three typical metals: aluminum, cadmium and nickel, which the high concentration in soils and which the industries use, result in a daily significant exposure to humans. The three of them are suspected to be involved in carcinogenesis which implies genomic lesions. We propose to first study their genotoxic impact in vivo on primary normal human dermal fibroblast (NHDF) cells with comet assay at $\mathrm{pH} 7$ to measure DNA breaks occurrence. Then, to characterize the metal/DNA interaction by isothermal titration calorimetry (ITC).

Comet assay shows that $\mathrm{Cd}$ and $\mathrm{Ni}$ are genotoxic, they are responsible for DNA breaks starting from $1.10^{-4}$ mol. $\mathrm{L}^{-1}$ and $5.10^{-2}$ mol. $\mathrm{L}^{-1}$, respectively whereas $\mathrm{Al}$ has no effect (on DNA at $\mathrm{pH} 7$ ) as studied by ITC at $\mathrm{pH}$ 7. Cd and $\mathrm{Ni}$ present an electrostatic interaction with DNA phosphate groups. At high Cd concentration, a DNA condensation is observed by contrast. Al has no interaction with DNA phosphate groups, but at $\mathrm{pH} 4$ the electrostatic interaction is strong and the same DNA condensation phenomenon is observed. Metal genotoxic effect seems linked to the electrostatic interaction on DNA phosphate groups. Genotoxic power evolves in parallel to DNA phosphate interaction strength as $\mathrm{Cd}>\mathrm{Ni}>\mathrm{Al}$. If this study shows that metals do not directly break DNA, this binding could be a preferential site for damage due to reactive oxygen species.
\end{abstract}

Key words: aluminum; cadmium; nickel; isothermal titration calorimetry; genotoxicity; DNA binding 


\section{Introduction}

This study examines three metal, aluminum, cadmium and nickel, (which the high concentration in soils and which the industries use result in a daily significant exposure to humans. If toxicity of $\mathrm{Cd}$ and $\mathrm{Ni}$ is clearly established and demonstrate, it is not the case of $\mathrm{Al}$ whose effects are still controversial. Indeed, chronic exposure to $\mathrm{Cd}$ leads to tubular and glomerular dysfunction and then to renal insufficiency accompanied by bone disorders [1-3]. Since 1973, Cd is considered as responsible for professional diseases and has been classified in group 1 carcinogenic agent by the IARC [4]. In the same way, $\mathrm{Ni}$, which we handle daily with coins, jewelry or zippers, is recognized as one of the most allergenic metals [5, 6]. Moreover, besides leading to contact dermatitis, this metal is also classified as a potentially carcinogenic substance for humans by the IARC [7] and a chronic exposure to nickel is registered as a risk factor for lung cancer in the professional illness table. Finally, $\mathrm{Al}$ is said to be responsible for dialysis encephalopathy, osteoporosis and osteomalacia [8]. It accumulates in bones and brain leading to memory and learning disorders, but also inducing neurodegenerative pathologies [9-11]. If its role in breast cancer has been mentioned [12, 13] but not clearly established, according to precautionary principle its action as a carcinogen cannot be totally invalidated.

However, if the entire mechanism of action of these metals remains mostly unknown, their carcinogenesis abilities cannot be ignored. In this condition, it is relevant to consider their impact on the genome that, when altered, may lead to tumors. The aim of this study is to determine if these metals have an impact on the genome in physiological conditions. Then, if so, to quantify and model this impact. So, at first, the impact on $\mathrm{Al}, \mathrm{Cd}$ and $\mathrm{Ni}$ on the genome was evaluated on human cells by comets assay. Secondly, the chemical interaction between metals and DNA was defined, using isothermal titration calorimetry (ITC), then the interaction was studied by the McGhee von Hippel model [14].

\section{Materials and methods}

\subsection{Reagents}

The metal used were chlorides salts at high purity (99.9\%): Cd (II) and $\mathrm{Ni}$ (II) were from Aldrich $^{\circledR}$ and $\mathrm{Al}$ (III) from Fluka ${ }^{\circledR}$ analytical.

Primary normal human dermal fibroblasts (NHDF) were purchased from Lonza ${ }^{\circledR}$. Fibroblast basal medium-2 (FBM-2) supplemented with a growth kit containing $10 \mathrm{~mL}$ of fetal bovine serum, $0.5 \mathrm{~mL}$ of insulin, $0.5 \mathrm{~mL}$ of gentamicin sulfate amphotericin-B (GA-1000), and 0.5 
$\mathrm{mL}$ of r-human fibroblast growth factor-B were also from Lonza ${ }^{\circledR}$. During the harvest, NHDF

Sodium chloride $(\mathrm{NaCl})$ used in aqueous solution was from Sigma-Aldrich ${ }^{\circledast}$ and $\geq 99.5 \%$ of purity.

The TRIS (2-amino-2-hydroxyméthyl-1,3-propanediol) and MES (2-(NMorpholino)ethanesulfonic acid) buffers were from AppliChem of Biochemical Chemical Synthesis Services and from Sigma-Aldrich ${ }^{\circledR}$ and $\geq 99.5 \%$ of purity (titration) respectively.

The DNA used in thermal analysis experiment was low molecule weight from salmon sperm from Sigma-Aldrich ${ }^{\circledR}$.

Low Melting Point and Normal melting Point agars, L-lauroyl sarcosinate, dimethylsulfoxide, Triton X-100, ethidium bromide and methanol of analytical grade were from Sigma-Aldrich ${ }^{\circledR}$

\subsection{Cell culture}

Fibroblasts were routinely cultured in culture medium (FBM-2) in sterile boxes for cell culture with an area of $75 \mathrm{~cm}^{2}$ (T75) and maintained at $37^{\circ} \mathrm{C}$ and $5 \% \mathrm{CO}_{2}$. When cells were at confluence, FBM-2 was discarded and cells were treated with the trypsin solution during 2 minutes at $37^{\circ} \mathrm{C}$. The cell suspension obtained was diluted in FBM-2 and introduced into new T75 boxes. NHDF were then used for all experiments between passages 5 and 8 .

\subsection{Comet assay}

The comet assay performed was the alkaline comet assay as described by Singh [15]. NHDF were harvested, put in a 24 multi-wells plate to get 160000 cells per well and incubated during 24 hours before treatment. At the end of the 2 hours exposure period with a concentration of $\mathrm{Cd}$ ranges between 50 and $500 \mu \mathrm{mol} . \mathrm{L}^{-1}$, Ni from 5 to $50 \mathrm{mmol} \cdot \mathrm{L}^{-1}$ and $\mathrm{Al}$ from 1 to 10 mmol. $\mathrm{L}^{-1}$, cells were trypsinized with $0.05 \%$ trypsin-0.02\% EDTA in PBS for 35 minutes at $37^{\circ} \mathrm{C}$, and centrifuged at $1200 \mathrm{rpm}$ for 5 minutes. Following the trypsin/EDTA treatment, cells were mixed with PBS and centrifuged at $1200 \mathrm{rpm}$ for 5 minutes. During cell centrifugation, a first layer of $85 \mu 1$ of $0.8 \%$ NMP agarose (in PBS) was deposited on microscope slides, previously coated with $2 \%$ NMP agarose (in PBS) and allowed to dry for 12 hours. Coverslips were placed over this layer and the agarose was allowed to harden during 5 minutes on ice. After centrifugation coverslips were removed, cell pellets were mixed with $75 \mu 1$ of $0.5 \%$ LMP agarose (in PBS) and deposited onto the microscope slides. Two slides were prepared for each sample. Coverslips were placed over the cell layer and the agarose was allowed to harden during 5 minutes on ice. Then, coverslips were removed, and a 
third layer with $85 \mu 1$ of $0.8 \%$ agarose (in PBS) was added over the cells. A coverslip was applied and the agarose was allowed to solidify during 5 minutes on ice.

The slides were immersed in freshly prepared lysis solution $(2.5 \mathrm{M} \mathrm{NaCl}, 100 \mathrm{mM} \mathrm{Na} 2$ EDTA, 10 mM Tris (pH 10), 1\% L-lauroyl sarcosinate, with $10 \%$ dimethylsulfoxide and $1 \%$ Triton X-100 added just before use) for $90 \mathrm{~min}$ at $4^{\circ} \mathrm{C}$. After the lysis procedure, the slides were placed side-by-side in a horizontal gel electrophoresis tank, which was filled with fresh electrophoresis buffer ( $300 \mathrm{mM} \mathrm{NaOH}, 1 \mathrm{mM} \mathrm{Na} 2$ EDTA $\mathrm{pH}>13)$. The slides remained in the buffer for 20 minutes at $25^{\circ} \mathrm{C}$ to allow DNA unwinding. Electrophoresis was then carried out in the same buffer for 20 minutes at $25 \mathrm{~V}$ and $300 \mathrm{~mA}$. Following electrophoresis, the slides were washed three times for 5 minutes each with $0.4 \mathrm{M}$ Tris buffer $(\mathrm{pH} 7.5)$ to neutralize the alkali. Finally, the slides were rinsed with ultra-pure water, dehydrated in $100 \%$ methanol and dried for 12 hours at room temperature. Each slide was stained with $50 \mu 1$ of $2 \mu \mathrm{g} / \mathrm{ml}$ ethidium bromide and covered with a coverslip.

The cells were examined at 250X Magnification using a BX53-RFL fluorescence microscope (Olympus Optical Co. Tokyo, Japan) equipped with a U-MWG2 dichroic mirror (band-pass filter, 510-550 nm; long-pass filter, $590 \mathrm{~nm}$ ) and a UPLFLN 20x objective. Image analysis was performed using the Komet software (version 6.0 Andor Technology, Belfast, Northern Ireland). A total of 50 randomly selected cells were analyzed per slide using Fenestra Komet 6.0 image analysis software Andor Technology (Belfast, Northern Ireland). DNA damage was expressed as the Olive Tail Moment (OTM; arbitrary units); 100 OTM values were determined for each sample, 50 from each of two separate slides/sample. The 100 calculated OTM values by sample were distributed into 30 classes between the minimal and the maximal values: each class interval corresponded to 1.4 OTM arbitrary units. A non-linear regression analysis was performed on the OTM distribution frequencies by using a $\chi^{2}$ function with Table Curve 2D software (version 5.0; Jandel Scientific Software, San Rafael, CA). The calculated degrees of freedom (n) for this function were quantitative measures of the DNA damage for a sample $[16,17]$. The $\mathrm{n}$ was termed $\chi^{2}$ OTM and was used as the sole parameter for assessing levels of DNA damage. The significance of the differences between $\chi^{2}$ OTM values of control and treated cells was analysed using Student's t-test.

\subsection{Calorimetry}

Isothermal Titration Calorimetry (ITC) was performed on a Microcal ITC 200 instrument (Microcal, Northampton, United States) at $37^{\circ} \mathrm{C}$ unless otherwise specified in TRIS ( $5 \mathrm{mM}$ and $\mathrm{pH}=7)$ or MES $(5 \mathrm{mM}$ and $\mathrm{pH}=4)$ buffer. The metal solution $(8 \mathrm{mM}$ for $\mathrm{Al}$ and $10 \mathrm{mM}$ 
for $\mathrm{Cd}$ and $\mathrm{Ni}$ ) was added sequentially after an initial injection of $0.1 \mu \mathrm{L}$ (not used in data fitting) [18] by adding 30 injections of $1.3 \mu \mathrm{L}$ at $90 \mathrm{~s}$ of intervals. The measuring cell contained a DNA solution at the initial concentration of $2 \mathrm{mmol} . \mathrm{L}^{-1}$ of phosphate groups, solubilized in the same buffer and at the same $\mathrm{pH}$, than the metal solution. These concentrations (a priori high) were chosen in order to obtain the most accurate heat flow and do not change the parameters and the thermodynamics of the interaction. The reference power and the feedback gain were modified according to the thermal power of peaks. Each experiment was performed three times. Peaks were integrated and heats of dilution subtracted, yielding the heat values of each injections.

The binding between metal cations and phosphate groups of DNA were studied using McGhee von Hippel model [19]. DNA is considered as a mono-dimensional lattice with n sites i.e. phosphates. Each metal cation during the binding blocks the accessibility to L number of phosphates. Along the DNA saturation, the number of metal cations bound per nucleotide is defined as: $\quad \theta=\frac{\left[M^{L+}\right]}{\left[P^{-}\right]_{t}}$,

Here $\left[\mathrm{M}^{\mathrm{L}+}\right]$ and $\left[\mathrm{P}^{-}\right]_{t}$ represent the concentration of metal cation bound and the total concentration of DNA phosphate groups, respectively. Considering the ionic interaction, the $\theta$ value is ranged between 0 and $\mathrm{n} / \mathrm{L}$. If infinite lattice is considered and end-effects disregarded, the theoretical isotherms of McGhee von Hippel [14] is obtained:

$$
\frac{\theta}{\left[M^{L+}\right]_{f}}=K \cdot(n-L \cdot \theta) \cdot\left(\frac{n-L \cdot \theta}{n-(L-1) \cdot \theta}\right)^{(L-1)}
$$

Here variables are defined as in $(1),\left[\mathrm{M}^{\mathrm{L}+}\right]_{\mathrm{f}}$ is the free metal cation concentration, $\mathrm{K}$ is the binding constant and $\mathrm{n}$ is the number of repeating units per DNA (in our case the value is equal to 1 due to the consideration of DNA phosphate group concentration).

For $\mathrm{L}>1$, an apparent negative cooperation between ligands occurs during binding frequently called entropic resistance to saturation. In the ionic interaction, L can represent the size but also the charge of metal cation. The binding polynomial can be written as:

$$
\left(\left[M^{L+}\right]_{t}-\theta \cdot\left[P^{-}\right]_{t}\right) \cdot(n-L \cdot \theta)^{L}-\frac{\theta \cdot(n-\theta \cdot(L-1))^{(L-1)}}{K}=0
$$

The polynomial obtained possesses only one root presenting physical meaning i.e. being superior to zero and lower than $1 / \mathrm{L}$.

The determination of the root was performed using a library of numerical routines from NAG (Numerical Algorithms Group, Inc) included in Origin 9.1. The NAG function c05tbc is a 
function which finds a non-linear system equations solution by a modification of the Powell value and coefficient of determination values equal to $10^{-9}$ and 0.995 were respectively reached.

For each injection, considering the mass balance and the cell volume, the total concentration of each reactant in the cell is calculated. From these concentrations, the iteration process leads to the determination of $\mathrm{L}, \mathrm{K}$ and $\theta$. Finally, the heat effect for each injection $\mathrm{q}_{\mathrm{i}}$ is calculated from:

$$
q_{i}=\frac{\partial \theta}{\partial R}
$$

where R represent the ratio ${ }^{\left[M^{L+}\right]_{t}} /\left[P^{-}\right]_{t}$.

The use of Levenberg-Marquardt algorithm in a nonlinear curve fitting procedure allows the determination of $\mathrm{L}, \mathrm{K}$ and $\Delta \mathrm{H}^{\circ}$ values from the experimental data.

\section{Results}

\subsection{Comet assay}

Comet assay was performed in order to measure the induction of DNA-strand breaks by metals.

As comet assay was significant by using metal concentrations lower than those inducing cytotoxicity, the value was determined by MTT assay at $2 \mathrm{~h}$. Then IC50 was found equal to $1.10^{-3} \mathrm{M}, 3.10^{-3} \mathrm{M}$ and $4.10^{-3} \mathrm{M}$ for $\mathrm{Cd}, \mathrm{Ni}$ and $\mathrm{Al}$ respectively (data not shown).

Cadmium and nickel induced a significant increase of DNA-lesions, while aluminium did not exert genotoxic activity. Cadmium induced the most important DNA damage with a significant induction of comets at $100 \mu$ mol. $\mathrm{L}^{-1}$ (fig.1). Nickel appeared far less active, with comets significantly present at 50 mmol. $\mathrm{L}^{-1}(\mathrm{p}<0.001)$ (fig.2), a concentration which is about $10^{6}$ over blood concentration [21] (Ivanenko et al., 2012). Aluminium was not responsible of any damaging impact on DNA at concentrations tested (fig.3). 
Figure 1: Cadmium impact on DNA. The first bar is the positive control. Significant assay are represented by the dark bars with stars $(p<0.001)$

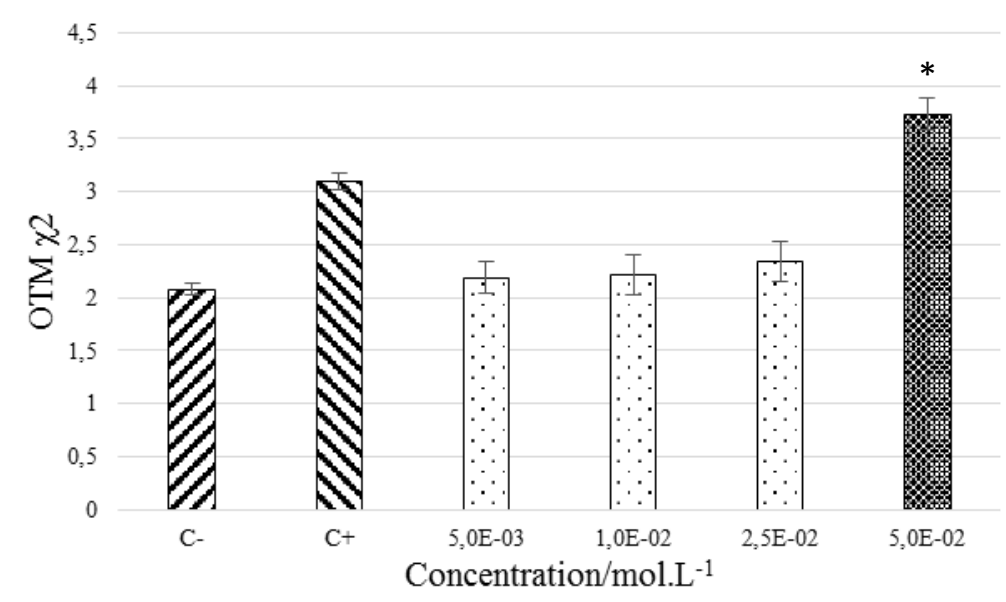

Figure 2: Nickel impact on DNA. The first bar is the positive control. Significant assay is represented by the dark bar with the star $(p<0.001)$ 


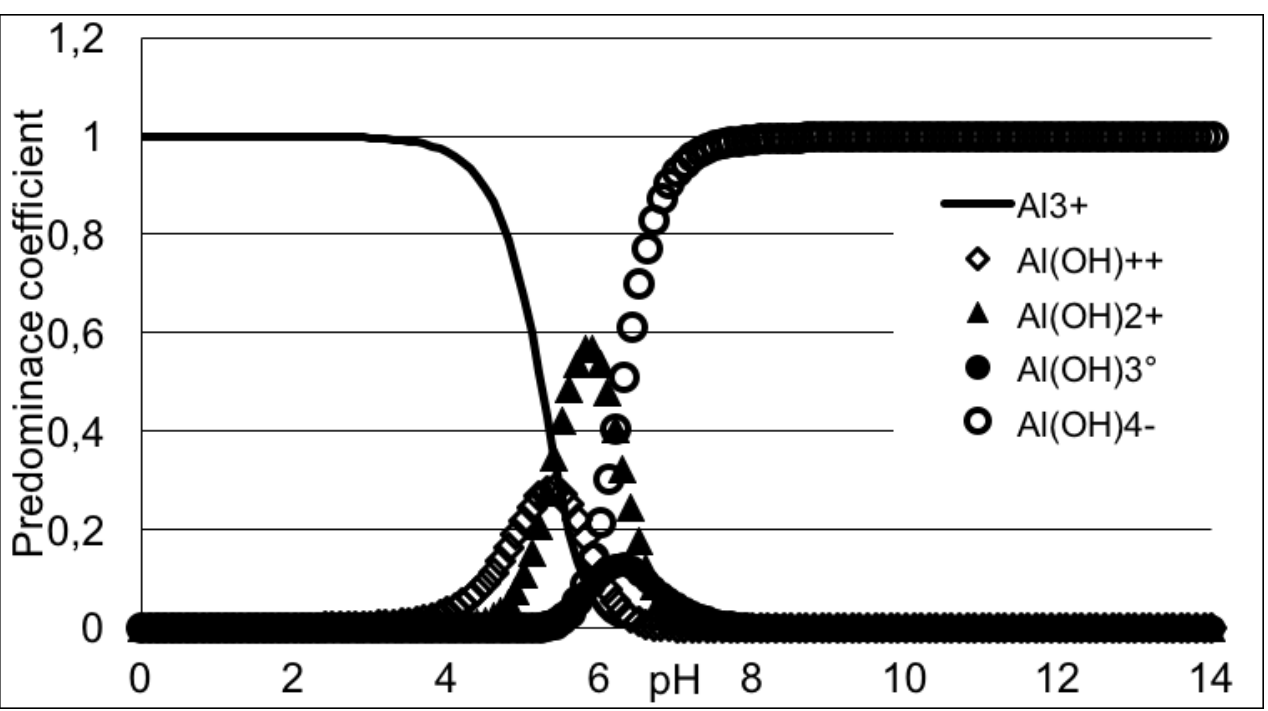

Figure 4: Species predominance diagram of aluminum in water at $\mathrm{NaCl}$ concentration $=0.150 \mathrm{~mol} . \mathrm{L}^{-1}$ 


\subsection{Isothermal titration calorimetry}

At first, interaction between each metal and DNA are performed at constant ionic strength obtained with a $\mathrm{NaCl}$ solution $\left(0.150 \mathrm{~mol} \cdot \mathrm{L}^{-1}\right)$ and $\mathrm{pH} 7$ in order to mimic the physiological conditions, $\mathrm{Al}$ was tested also at $\mathrm{pH} 4$. Results obtained for interactions are given in Table 1.

\begin{tabular}{lccccc}
\hline \multicolumn{1}{c}{ Metal } & $\mathbf{p H}$ & $\mathbf{L}$ & $\mathbf{K} / \mathbf{L} \cdot \mathbf{m o l}{ }^{-1}$ & $\Delta \mathbf{H}^{\circ} / \mathbf{k J} \cdot \mathbf{m o l}$ & $\mathbf{R}^{-1}$ \\
\hline $\mathbf{C d}^{2+}$ & 7 & $6.7 \pm 0.4$ & $57 \pm 4$ & $-24.4 \pm 1.2$ & 0.993 \\
$\mathbf{N i}^{2+}$ & 7 & $6.5 \pm 0.2$ & $26 \pm 3$ & $-20.3 \pm 0.9$ & 0.999 \\
$\mathbf{A l}^{3+}$ & 7 & $\mathrm{NB}^{\mathrm{a}}$ & $\mathrm{NB}$ & $\mathrm{NB}$ & $\mathrm{NB}$ \\
$\mathbf{A l}^{3+}$ & 4 & $3.4 \pm 0.1$ & $2021 \pm 57$ & $8.4 \pm 0.4$ & 0.999
\end{tabular}

Table 1: Thermodynamic Parameters of Interaction at $37^{\circ} \mathrm{C},(\mathrm{pH}=7$ in TRIS buffer or $\mathrm{pH}=$ 4 in MES buffer) and $\mathrm{NaCl}$ concentration of 0.150 mol. $\mathrm{L}^{-1}$

${ }^{\mathrm{a}} \mathrm{NB}=$ not bound

The non-specific electrostatic binding of the model is validated by the good values of the coefficient of determination $\left(\mathrm{R}^{2}\right)$. The enthalpy driven of the process confirms that the binding is driven by an electrostatic interaction between the negative charge of the DNA phosphate groups and the positive charge of metal cation. The binding of metal cation on the phosphate groups decreases the charge density of DNA and then diminishes the affinity of $\mathrm{Ni}^{2+}$ and $\mathrm{Cd}^{2+}$ toward DNA. The interaction intensity evolves with metal concentration. Indeed, affinity is high at weak cation concentration and decreases when concentration increases (due to the DNA charge density diminution). This nature of the interaction excludes the validity for using a single independent site model and may lead to thermodynamic parameters without sense.

In these experimental conditions, divalent cations exhibit similar thermodynamic parameters with a binding constant and enthalpy slightly more favorable to $\mathrm{Cd}^{2+}$ than $\mathrm{Ni}^{2+}$. This stronger affinity of $\mathrm{Cd}^{2+}$ to phosphate groups, can be related to the weaker solubility of $\mathrm{Cd}_{3}\left(\mathrm{PO}_{4}\right)_{2}$ than $\mathrm{Ni}_{3}\left(\mathrm{PO}_{4}\right)_{2}$. Moreover, this difference of behavior on the affinity to DNA was observed in a previous study of the interaction between $\mathrm{Cd}^{2+}$ and $\mathrm{Ni}^{2+}$ on DNA helicity [28]. At $\mathrm{pH}$ 7, no binding can be observed with aluminum, which confirm $\mathrm{Wu}$ et al. [29] observations performed at $\mathrm{pH}=6$. As said above, in acid conditions aluminum is present under $\mathrm{Al}^{3+}$ specie, therefore interaction experiments were performed at $\mathrm{pH}=4$ in order to compare the interaction of $\mathrm{Al}^{3+}$ to $\mathrm{Cd}^{2+}$ and $\mathrm{Ni}^{2+}$ (fig.5). This result clearly shows that from a chemical point of view, aluminum interacts with DNA only under cationic form. The interaction between $\mathrm{Al}^{3+}$ and DNA is largely entropy driven coupled with an unfavorable enthalpy. This 
calorimetric signature and the $\mathrm{pH}$ range of binding were already mentioned in a previous study using a single set of identical sites model [29]. This strong interaction of $\mathrm{Al}^{3+}$ with phosphates is well known and frequently met in biological systems but the variation of the affinity during the binding is not $[30,31]$. The electrostatic component of the interaction is in agreement with DFT quantum mechanical calculations describing the phosphate of DNA as strong chelators $[32,33]$.
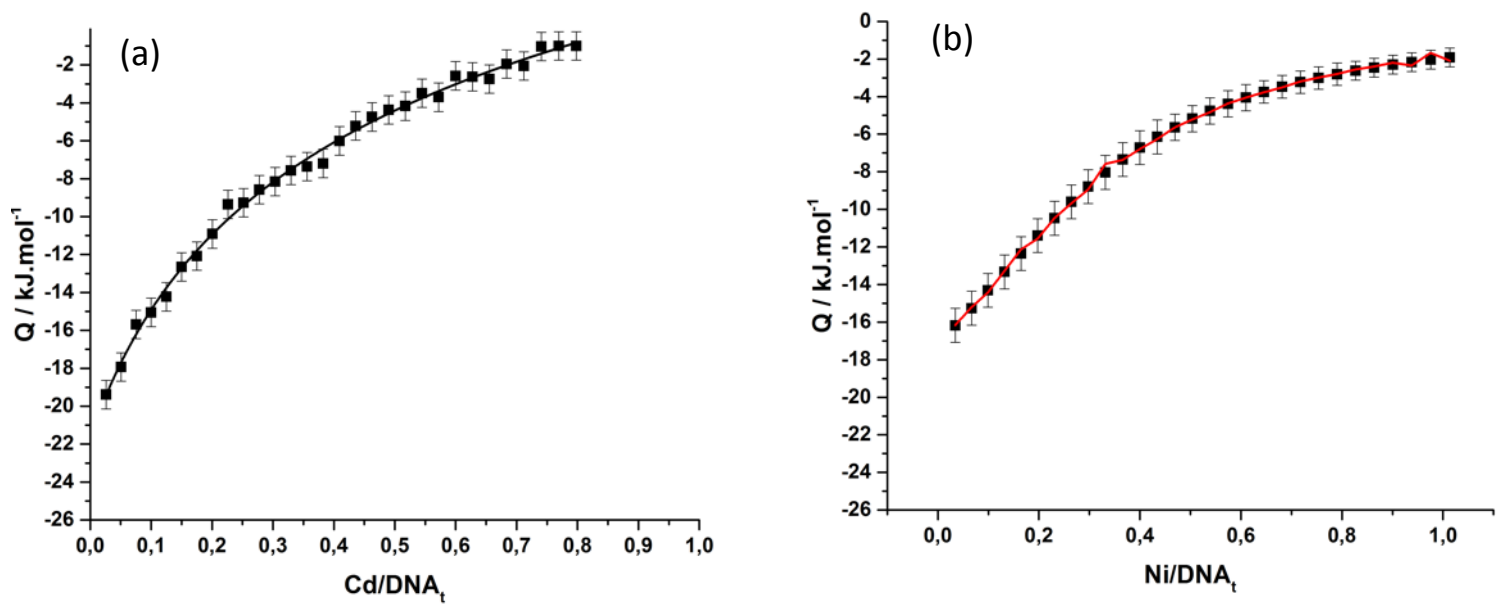

(c)

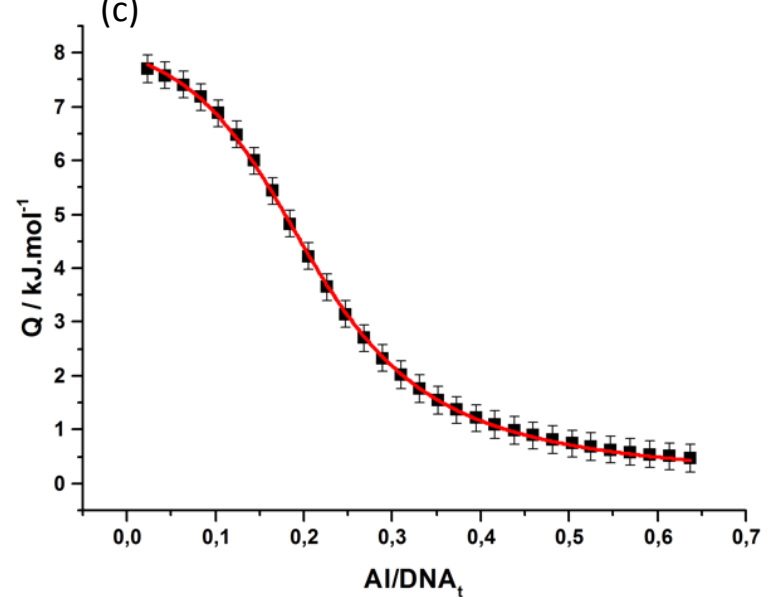

Figure 5: (a) Isothermal titration curves of $\mathrm{Cd}^{2+}$, at $37^{\circ} \mathrm{C}$ at $0.150 \mathrm{~mol} . \mathrm{L}-1 \mathrm{NaCl}$ in TRIS buffer at pH 7. (b) Isothermal titration curves of $\mathrm{Ni}^{2+}$, at $37^{\circ} \mathrm{C}$ at $0.150 \mathrm{~mol} . \mathrm{L}-1 \mathrm{NaCl}$ in TRIS buffer at $\mathrm{pH}$ 7. (c) Isothermal titration curves of $\mathrm{Al}^{3+}$, at $37^{\circ} \mathrm{C}$ at 0.150 mol.L-1 NaCl in MES buffer at pH 4. Error bars correspond to the mean standard error. 


\section{Ionic strength influence}

As electrostatic interaction and binding constant are strongly dependent of the ionic strength, experiments are performed next at different $\mathrm{NaCl}$ concentrations [34, 35]. Indeed, the electrostatic component of the interaction depends on the salt concentration and on the nonelectrostatic component, as described by the following equation [36]:

$$
\ln (K)=\ln \left(K_{N E}\right)-n \cdot \ln [\mathrm{NaCl}]
$$

here $\mathrm{K}_{\mathrm{NE}}$ represents the binding constant of the non-electrostatic component of the interaction, $\mathrm{n}$ is the number of counter-ions displaced from the phosphate groups of DNA and $[\mathrm{NaCl}]$ is the salt concentration.

Ionic strength is then decreased by diminishing the $\mathrm{NaCl}$ concentrations at $\mathrm{pH}=7$ for $\mathrm{Cd}^{2+}$ and $\mathrm{Ni}^{2+}$. In the $\mathrm{Al}^{3+}$ case, $\mathrm{pH}$ is fixed at 4 to isolate the trivalent specie aluminum. The affinity constant evolution versus the sodium chloride concentration is plotted in figure 6 . The constant affinity at value weak ionic strength can only be measured on $\mathrm{Ni}^{2+}$ titration. Indeed, in the case of $\mathrm{Cd}^{2+}$ a condensation of DNA occurred. This behavior is often observed when a critical concentration of cation is reached. The DNA phosphate groups involve a charge density equal to $-0,4712 \mathrm{nC} \cdot \mathrm{m}^{-1}$ (two negative charges per $0.34 \mathrm{~nm}$ ). When metal cation is added, the negative charges of DNA backbones are neutralized and lead to the condensation and aggregation of DNA (the phenomenon is easily observed due to the turbidity occurring in the sample cell) $[37,38]$. This DNA condensation during $\mathrm{Cd}^{2+}$ titration can be observed in figure 7. Since a value of $\mathrm{Cd}^{2+} / \mathrm{DNA}-\mathrm{P}$ about 0.2 is reached, a large endothermic peak appears due to DNA condensation. This behavior does not allow an usable fit of the titration curve. This value of 0.2 has already been observed in a previous electrophoresis study mentioning a $\mathrm{Cd}^{2+}$ /DNA stoichiometry of $1 / 5$ i.e. 0.2 [39]. Once again this condensation process occurs only with $\mathrm{Cd}^{2+}$, which confirms the strongest interaction of $\mathrm{Cd}^{2+}$ versus $\mathrm{Ni}^{2+}$. This absence of transformations in $\mathrm{Ni}^{2+}$ interaction case is in accordance with UV spectroscopic investigations [40]. 

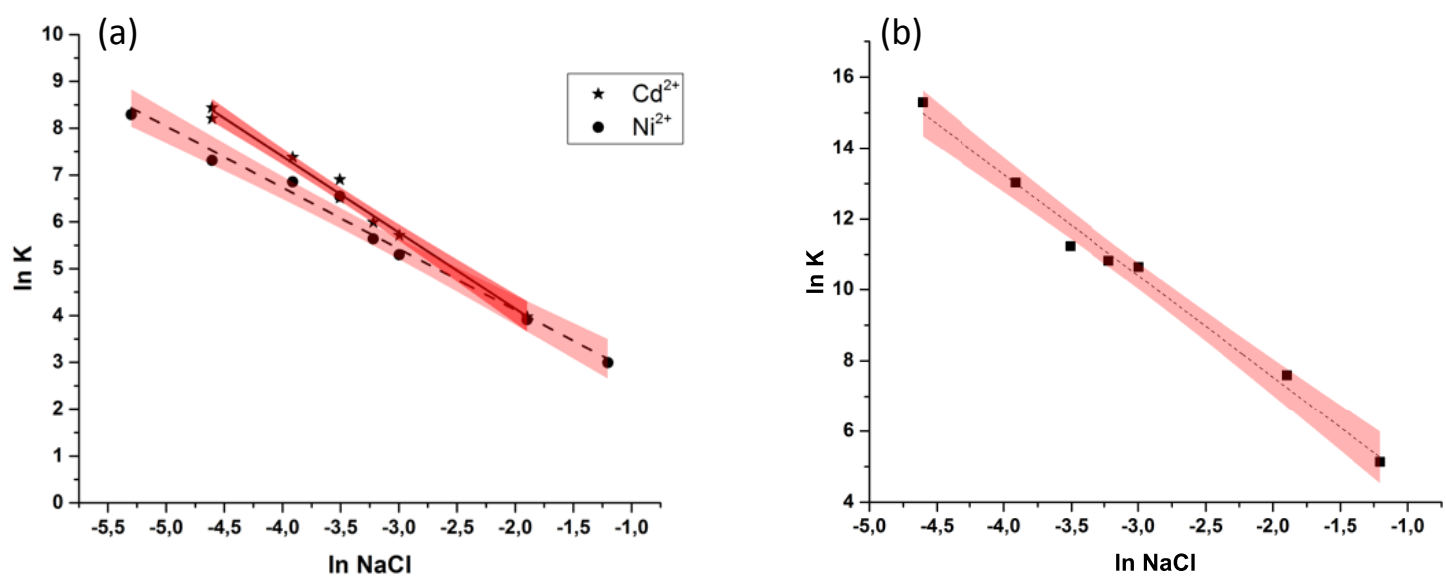

Figure 6: Dependence of the affinity constant on sodium chloride concentration. (a) Dashed and solid lines represent the linear fitting for $\mathrm{Cd}^{2+}$ and $\mathrm{Ni}^{2+}$. (b) Dashed and solid lines represent the linear fitting for $\mathrm{Al}^{3+}$.The shade bands around the linear fits represent the confidence interval of $95 \%$. 


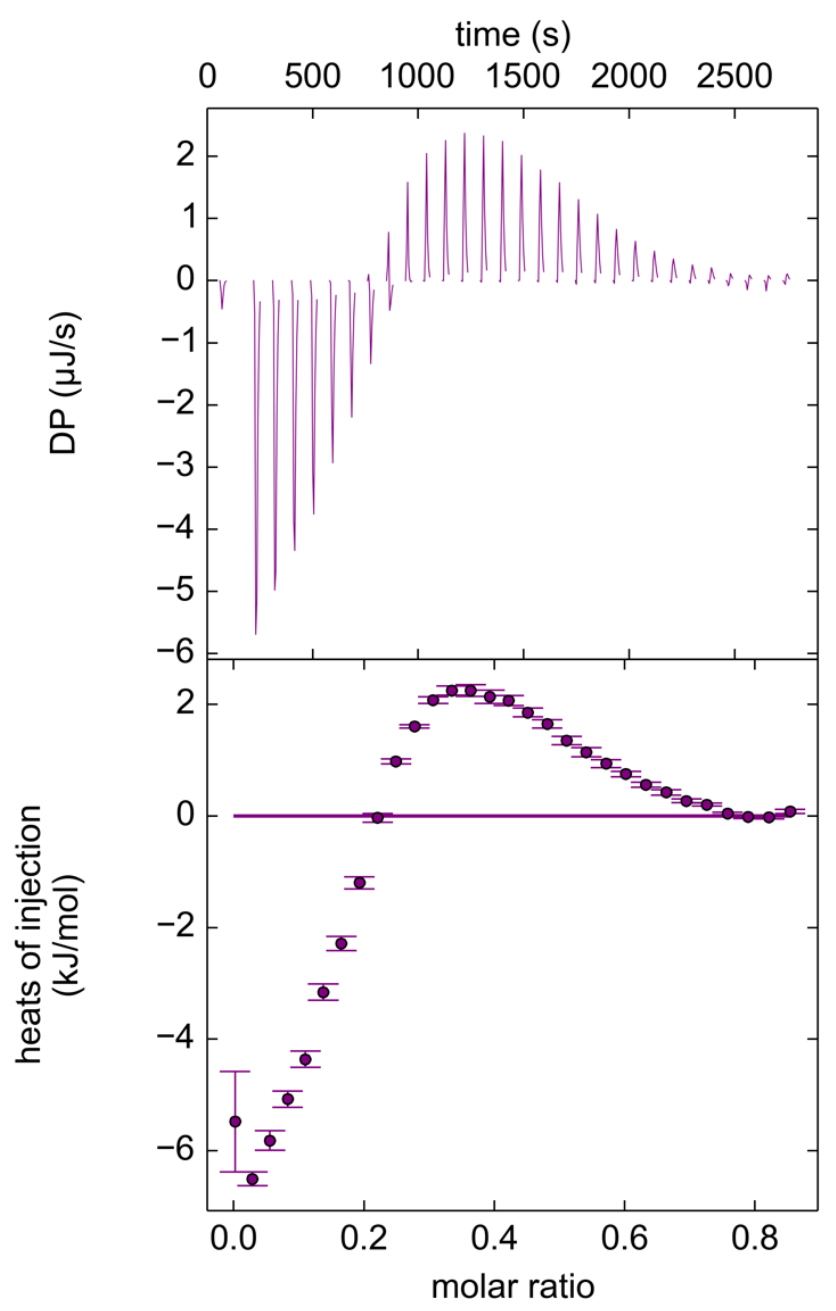

Figure 7: Isothermal titration curve of Cd2+ binding to DNA at $37^{\circ} \mathrm{C}$ in TRIS buffer at 5 mmol.L-1 with $\mathrm{NaCl}$ concentration lower than $5 \mathrm{mM}$. The upper curve shows the heat flow versus the time and the lower part shows the heat versus the Cd2+/DNA-P molar ratio [41].

\section{Interaction mechanism}

The natural logarithm plot of the affinity constant versus the natural logarithm of $\mathrm{NaCl}$ concentration exhibits a linear evolution associated with coefficients of determination $\left(\mathrm{R}^{2}\right)$ equal to $0.988,0.983$ and 0.989 for $\mathrm{Ni}^{2+}, \mathrm{Cd}^{2+}$ (fig. 6.A) and $\mathrm{Al}^{3+}$ (fig. 6.B), respectively. This behavior is characteristic of the coulombic component governing the interaction. Indeed, $\mathrm{Al}^{3+}$, $\mathrm{Cd}^{2+}$ and $\mathrm{Ni}^{2+}$ need to displace $\mathrm{Na}^{+}$to bind DNA phosphate groups. The increase of ionic strength involves a less favorable electrostatic entropy leading to a weaker binding. This is observed in high $\mathrm{NaCl}$ concentration than at low [42]. In the $\mathrm{Al}^{3+}$ case, the slope value is equal to $2.86 \pm 0.13$, leading to the displacement of 2.86 charges to bind one $\mathrm{Al}^{3+}$ ion. This displacement of counter-ions by aluminum is well known and can occur even with divalent counter-ions such as $\mathrm{Mg}^{2+}$ [43]. The amounts of counter-ions displaced by binding of $\mathrm{Cd}^{2+}$ and $\mathrm{Ni}^{2+}$ is equal to $1.63 \pm 0.07$ and $1.38 \pm 0.07$ respectively, confirming the strongest affinity 
of $\mathrm{Cd}^{2+}$ versus $\mathrm{Ni}^{2+}$ to DNA. These values of exchanged counter-ions are in the range of the

\section{Discussion}

Comet assay showed than cadmium and nickel had an impact on DNA while aluminum did not, at $\mathrm{pH}$ 7. These observations were congruent with thermal analysis results. Indeed, the most damaging metal was $\mathrm{Cd}^{2+}$, according to comet assay, and it was also the strongest linked to DNA. $\mathrm{Ni}^{2+}$ had an intermediate effect in both experiments, and aluminum did not damaged DNA in comet assay and was not linked to DNA phosphates. This may be explained by considering that at $\mathrm{pH} 7$ aluminum is mainly present under $\left[\mathrm{Al}(\mathrm{OH})_{4}\right]^{-}$form. To obtain $\mathrm{Al}^{3+}$ the $\mathrm{pH}$ value must be lower than 4 but these acidic conditions are responsible for cytotoxicity, mutagenic and clastogenic effects on cells [47, 48]. In this condition, legitimate questions can be raised about studies which find genotoxic effects over $40 \mu$ mol. $\mathrm{L}^{-1}$ of $\mathrm{Al}^{3+}$ concentrations. If $\mathrm{pH}$ is kept at $\mathrm{pH} 7$ (like in our study), $\mathrm{Al}^{3+}$ is no longer involved while other species, not entirely soluble, are present. According to comet results, no "tank effect" with aluminum appeared; undissolved aluminum amount did not impact DNA, there were no breaks. Over 40 $\mu$ mol. $\mathrm{L}^{-1}, \mathrm{Al}^{3+}$ should not be the specie tested.

According to these experiments, the genotoxicity of these metals seemed to be related to DNA phosphates: the strongest metal linked $\left(\mathrm{Cd}^{2+}\right)$ was also the most genotoxic. At the same time, the less bounded (aluminum) was the less toxic. However, these experiments confirm that the genotoxic effect of $\mathrm{Cd}^{2+}$ and $\mathrm{Ni}^{2+}$ is indirect [49]. Indeed, despite the high energy value of the bond, no heat peaks of thermal events have been measured excluding the possibility of direct

\section{DNA break.}

Metals are known to act indirectly by generating reactive oxygen species (ROS) [50-52] which are responsible for DNA base oxidation resulting in DNA breaks. Metal linked to DNA phosphate groups could modify DNA electric charge repartition and ease ROS access until bases. Furthermore, the condensation effect observed with $\mathrm{Cd}^{2+}$ means that this metal has an impact on DNA conformation which could lead, after too much tension, to DNA break. 


\section{Conclusions}

Two metals are responsible for a genotoxic effect under physiological conditions: cadmium and nickel. These two, in the same condition, present an electrostatic interaction between the positive cation metal charge and the negatively charged DNA phosphate groups, influenced by ionic strength. It appears that the most genotoxic metal (cadmium) is also the most bound metal to phosphate groups. Its interaction is so strong that a DNA condensation happens when every negative phosphate charges are saturated at high metal concentration. Furthermore, the strength of the interaction is highlighted by the amounts of displaced counter-ions: 1.63 and 1.38 for $\mathrm{Cd}^{2+}$ and $\mathrm{Ni}^{2+}$, respectively. Differences in genotoxicity of $\mathrm{Cd}$ and $\mathrm{Ni}$ may be due to the interaction of the metal with DNA. Indeed, Cd induces a stronger change on DNA electric field than Ni. This phenomenon might play a role by facilitating the effect of other active compounds such as ROS. For aluminum, the interaction with DNA is strong at $\mathrm{pH} 4$ and not observed at $\mathrm{pH}$ 7. As at these $\mathrm{pH}$ values the main species of this metal is $\mathrm{Al}^{3+}$ and $\left[\mathrm{Al}(\mathrm{OH})_{4}\right]^{-}$ respectively, solely $\mathrm{Al}^{3+}$ specie is able to bind strongly with phosphate groups of DNA as $\mathrm{Cd}^{2+}$ and $\mathrm{Ni}^{2+}$.

This behavior highlights that more than the metal nature itself, its specie may be considered to be involved in the genotoxicity. In this way a role of intracellular $\mathrm{pH}$ may be emphasized, a change in this $\mathrm{pH}$ range may induce a change of the metal species and so of its distribution and action.

'Conflicts of interest: none' 


\section{References}

[1] Jarup, L., Berglund, M., Elinder, C. G, 1998. Health effects of cadmium exposure a review of the literature and a risk estimate. Scand. J. Work. Environ. Health. 24, 240-240.

[2] Renugadevi, J., Milton Prabu, S., 2009. Naringenin protects against cadmium-induced oxidative renal dysfunction in rats. Toxicology. 256, 128-134.

[3] Nair, A. R., Smeets, k., Keunen, E., 2015. Renal cells exposed to cadmium in vitro and in vivo: normalizing gene expression data. J. Appl. Toxicol. 35, 478-84.

[4] Group, I. W, 1993. IARC monographs on the evaluation of carcinogenic risks to humans. IARC Monogr Eval. 58, 415.

[5] Schaumloffel, D., 2012. Nickel species: analysis and toxic effects. J. Trace. Elem. Med. Biol. 26, 1-6.

[6] Cavani, A, 2005. Breaking tolerance to nickel. Toxicology. 209, 119-121.

[7] Agent classified by the IARC Monographs, volumes 1-118 http://monographs.iarc.fr/ENG/Classification/ClassificationsAlphaOrder.pdf, 2015. Consulted : October 2017

[8] Crisponi, G., Nurchi, V. M., Faa, G, 2011. Human diseases related to alualuminium. Monatsh. Chem. 142, 331-40.

[9] Becaria, A., Campbell, A., Bondy, S. C, 2002. Aluminum as a toxicant. Toxicol. Ind. Health. 18, 309-20.

[10] Julka, D., Vasishta, R. K., Gill, K. D, 1996. Distribution of aluminum in different brain regions and body organs of rat. Biol. Trace. Elem. Res. 52, 181-92.

[11] Lal, B., Gupta, A., 1993. Aluminum ingestion alters behaviour and some neurochemicals in rats. J. Exp. Biol. 138, 5713-8. 
[12] Bakir, A., Darbre, P. D, 2015. Effect of aluminium on migration of oestrogen unresponsive MDA-MB-231 human breast cancer cells in culture. J. Inorg. Biochem. 152, $180-185$.

[13] Exley, C., Charles, L. M., Barr, L., Martin, C., Polwart, A., Darbre, P. D, 2007. Aluminium in human breast tissue. J. Inorg. Biochem. 107, 1344-1346.

[14] McGhee, J., von Hippel, P., 1974. Theoretical aspects of DNA-protein interactions: Cooperative and non-co-operative binding of large ligands to a one-dimensional homogeneous lattice. J. Mol. Biol. 86, 469-489.

[15] Singh, E. G., McCoy, M. T., Tice, R. R., Schneider, E. L., 1988. A simple technique for quantitation of low levels of NDA damage in individual cells. Exp. Cell. Res. 175, 184-191.

[16] Bauer, E., Recknagel, R. D., Fiedler, U., Wollweber, L., Bock, C., Greulich, K. O, 1998. The distribution of the tail moments in single cell gel electrophoresis (comet assay) obeys a chi-square (chi 2) not a gaussian distribution. Mutat. Res. 398, 101-110.

[17] Jean, S., De Méo, M., Sabatier, A. S., Laget, M., Hubaud, J. C., Verrando, P., Duménil, G, 2001. Evaluation of Sunscreen Protection in Human Melanocytes Exposed to UVA or UVB Irradiation Using the Alkaline Comet Assay. Photochem. Photobiol. 74, 417-423.

[18] Mizoue, L. S., Tellinghuisen, J., 2004. The role of backlash in the "first injection anomaly" in isothermal titration calorimetry. Anal. Biochem. 326, 125-127.

[19] Velazquez-Campoy, A., 2006. Ligand binding to one-dimensional lattice-like macromolecules: analysis of the McGhee-von Hippel theory implemented in isothermal titration calorimetry. Anal. Biochem. 348, 94-104.

[20] Roots of One or More Transcendental Equations. (s.d.). NAG Library Function Document nag_zero_nonlin_eqns_1 (c05tbc). Consulted: October 2017, on http://www.originlab.com/pdfs/nagcl09/manual/pdf/C05/c05tbc.pdf 
[21] Ivanenko, N. B., Solovyev, N. D., Ivanenko, A. A., Ganeev, A. A, 2012. Application of

Zeeman Graphite Furnace Atomic Absorption Spectrometry with High-Frequency Modulation Polarization for the Direct Determination of Aluminum, Beryllium, Cadmium, Chromium, Mercury, Manganese, Nickel, Lead, and Thallium in Human Blood. Arch. Environ. Contam. Toxicol. 63, 299-308.

[22] Oliveira, H., Monteiro, C., Pinho, F., Pinho, S., Miguel, J., Ferreira de Oliveira, P., Conceição, S., 2014. Cadmium-induced genotoxicity in human osteoblast-like cells. Mutation. Research. 775-776, 38-47.

[23] Dally, H., Hartwig, A, 1997. Induction and repair inhibition of oxidative DNA damage by nickel(II) and cadmium(II) in mammalian cells. Carcinogenesis. 18, 1021-1026.

[24] Willhite, C. C., Karyakina, N. A., Yokel, R. A., Yenugadhati, N., Wisniewski, T. M., Arnold, I. M., Krewski, D., 2014. Systematic review of potential health risks posed by pharmaceutical, occupational and consumer exposures to metallic and nanoscale aluminum, aluminum oxides, aluminum hydroxide and its soluble salts. Crit. Rev. Toxicol. 44, 1-80.

[25] Nordstrom, D. A., WesoMay, H. M., 1989. The Environmental Chemistry of Aluminum - Aqueous equilibrium data for mononuclear aluminum species (Chap 2). (G. Sposito, Éd.) Boca Raton FL: CRC Press.

[26] Palmer, D. A., Wesolowski, D. J., 1993. Aluminum Speciation and equilibria in aqueous solutions. Geochim. Cosmmochim. Acta. 57, 2929-2938.

[27] Wesolowski, D. J., 1992. Aluminum Speciation and equilibria in aqueous solution. Geochim. Cosmochim. Acta. 56, 1065-1092.

[28] Eichhorn, G. L., Shin, Y. A, 1968. Interaction of metal ions with polynucleotides and related compounds. The relative effect of various metal ions on DNA helicity. J. Am. Chem. Soc. $90,7323-7328$. 
[29] Wu, J., Du, F., Zhang, P., Khan, I. A., Chen, J., Li, Y., 2005. Thermodynamics of the interaction of aluminum ions with DNA: implications for the biological function of aluminum. J. Inorg. Biochem. 99, 1145-1154.

[30] Kiss, T., Zatta , P., Corain, B, 1996. Interaction of aluminum (III) with phosphatebinding sites biological aspects and implications. Coord. Chem. Rev. 149, 329-346.

[31] Mellor, J. W., 1924. A comprehensive Treatise of Inorganic and Theoritical Chemistry (Vol. 5). Green London: Eds Longmans.

[32] Luque, N. B., Mujika , J. I., Rezabal , E., Ugalde, J., 2014. Mapping the affinity of aluminum (III) for biophosphatres: interaction mode and binding affinity in 1:1 complexes. Phys. Chem. Chem. Phys. 16, 20107-20119.

[33] Mazzuca, D., Russo, N., Toscano, M., Grand, A., 2014. On the Interaction of Bare and Hydrated Aluminum Ion with Nucleic Acid Bases and Monophosphate Nucleotides. J. Phys. Chem. B. 110, 8815-8824.

[34] Mannin, G. S., 1969. Limiting laws and counter-ion condensation in polyelectrolyte solutions. Colligative properties. J. Chem. Phys. 51, 924-933.

[35] Manning, G. S., 1978. The molecular theory of polyelectrolyte solutions with applications to the electrostatic properties of nucleotides. Q. Rev. Biophys. 11, 179-246.

[36] Privalov, P. L., Dragan, A. I., Crane-Robinson, C., 2011. Interpreting protein/DNA interactions: distinguishing specific from non-specific and electrostatic from non-electrostatic components. Nucleic. Acids. Res. 39, 2483-2491.

[37] Wilson, R. W., Bloomfield, V. A., 1979. Counterion-induced condensation of desoxyribonucleic acid. A light-scattering study. Biochemistry. 18, 2192-2196.

[38] Widom, J., Baldwin, R. L., 1998. Catio-induced toroidal condensation of DNA: studies with Co(NH3)63+. J. Mol. Biol. 144, 431-453. 
[39] Li , Y., Xia, Y. L., Jiang, Y., Yan, X. P., 2008. Extrancting stochiometry, thermodynamics and kinetics for the interaction of DNA with cadmium ion by capillary electrophoresis on-line coupled with electrothermal atomic absorption spectrometry. Electrophoresis. 29, 1173-1179.

[40] Sorokin, A. V., Valeev , V. A., Gladchenko, G. O., Volchok, I. V., 1996. Interaction of bivalent copper, nickel, nmanganese ions with native DNA and its monomers. J. Inorg. Biochem. 63, 79-86.

[41] Keller, S., Vargas, C., Zhao, H., Piszczek, G., Brautigam, C. A., Schuck, P, 2012. HighPrecision Isothermal Titration Calorimetry with Automated Peak-Shape Analysis. Anal. Chem. 5066-5073, 84.

[42] Matulis, D., Rouzina, I., Bloomfield, V. A., 2002. Themrodynamics of cationic lipid binding to DNA and DNA condensation: roles of electrostatics and hydrophobicity. J. Am. Chem. Soc. 124, 7331-7342.

[43] Martin, R. B., 1992. Aluminum speciation in biology, Novartis Foundation Symposium. (D. K. Birchall, Éd.)

[44] Fenley, M. O., Russo, C., Manning, G. S, 2011. A Theoritical Assessment of the Oligolysine Model for ionic Interactions in Protein-DNA Complexes. J. Phys. Chem. B. 115, 9864-9872.

[45] Stickle, D. F., \& Fried, M. G., 2007. Cation binding linked to a sequence-specific CAPDNA interaction. Biophys. Chem. 126, 106-166.

[46] Revzin, A., 2000. The Biology of Nonspecific DNA-Protein Interactions. Boston: Ads CRC Press, Boca Raton, Ann Arbor.

[47] Güngör, N., Knaapen, A. M., Munnia, A., Peluso, M., Haenen, G., Chiu, R. K., van Schooten, F. J, 2010. Genotoxic effects of neutrophils and hypochlorous acid. Mutagenesis. $25,149-154$. 
[48] Morita, T., Nagaki, T., Fukuda, I., Okamura, K., 1992. Clastogenicity of low pH to various cultured mammalian cells. Mutat. Res. 268, 297-305.

[49] Beyersmann, D., Hartwig, A, 2008. Carcinogenic metal compounds: recent insight into molecular and cellular mechanisms. Arch Toxicol. 82, 493-512

[50] Bertin, G., Averbeck, D, 2006. Cadmium: cellular effects, modifications of biomolecules, modulation of DNA repair and genotoxic consequences (a review). Biochimie. 11, 15491559.

[51] Yao, Y., Costa, M., 2014. Toxicogenomic effect of nickel and beyond. Arch Toxicol. 88, $1645-1650$.

[52] Kumara, V., Balb, A., Gill, K. D., 2009. Aluminium-induced oxidative DNA damage recognition and cell-cycle disruption in different regions of rat brain. Toxicology. 264, 137144. 


\begin{tabular}{lccccc}
\hline \multicolumn{1}{c}{ Metal } & $\mathbf{p H}$ & $\mathbf{L}$ & $\mathbf{K} / \mathbf{L} . \mathbf{m o l}^{-1}$ & $\Delta \mathbf{H}^{\circ} / \mathbf{k J} \cdot \mathbf{m o l} \mathbf{l}^{-1}$ & $\mathbf{R}^{\mathbf{2}}$ \\
\hline $\mathrm{Cd}^{2+}$ & 7 & $6.7 \pm 0.4$ & $57 \pm 4$ & $-24.4 \pm 1.2$ & 0.993 \\
$\mathrm{Ni}^{2+}$ & 7 & $6.5 \pm 0.2$ & $26 \pm 3$ & $-20.3 \pm 0.9$ & 0.999 \\
$\mathrm{Al}^{3+}$ & 7 & $\mathrm{NB}^{\mathrm{a}}$ & $\mathrm{NB}$ & $\mathrm{NB}$ & $\mathrm{NB}$
\end{tabular}

$\begin{array}{llllll}\mathbf{A l}^{3+} & 4 & 3.4 \pm 0.1 & 2021 \pm 57 & 8.4 \pm 0.4 & 0.999\end{array}$

Table 1: Thermodynamic Parameters of Interaction at $37^{\circ} \mathrm{C},(\mathrm{pH}=7$ in TRIS buffer or $\mathrm{pH}=$ 4 in MES buffer) and $\mathrm{NaCl}$ concentration of 0.150 mol. $\mathrm{L}^{-1}$

${ }^{\mathrm{a}} \mathrm{NB}=$ not bound 


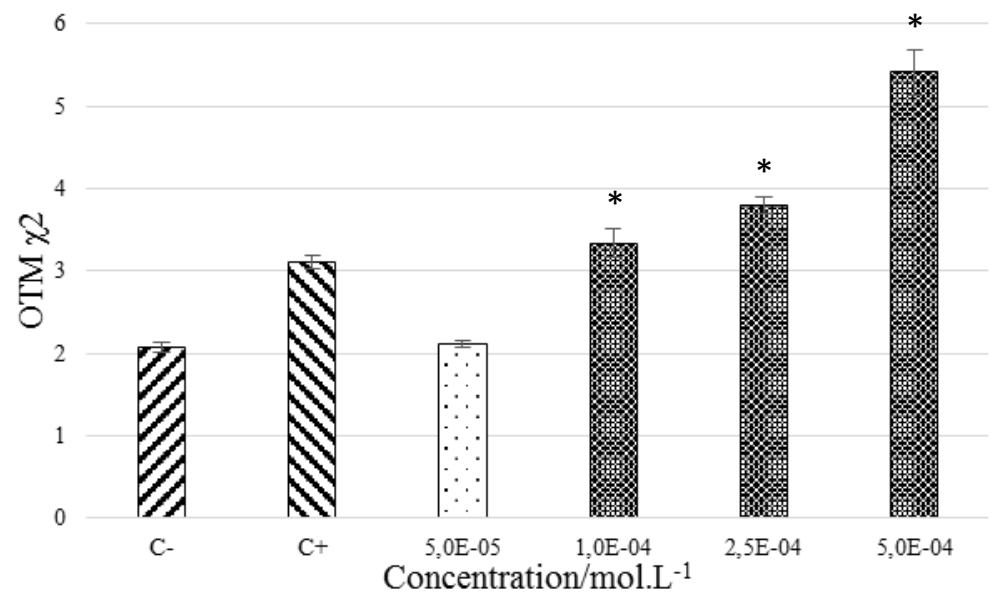

Figure 1: Cadmium impact on DNA. The first bar is the positive control. Significant assay are represented by the dark bars with stars $(p<0.001)$ 


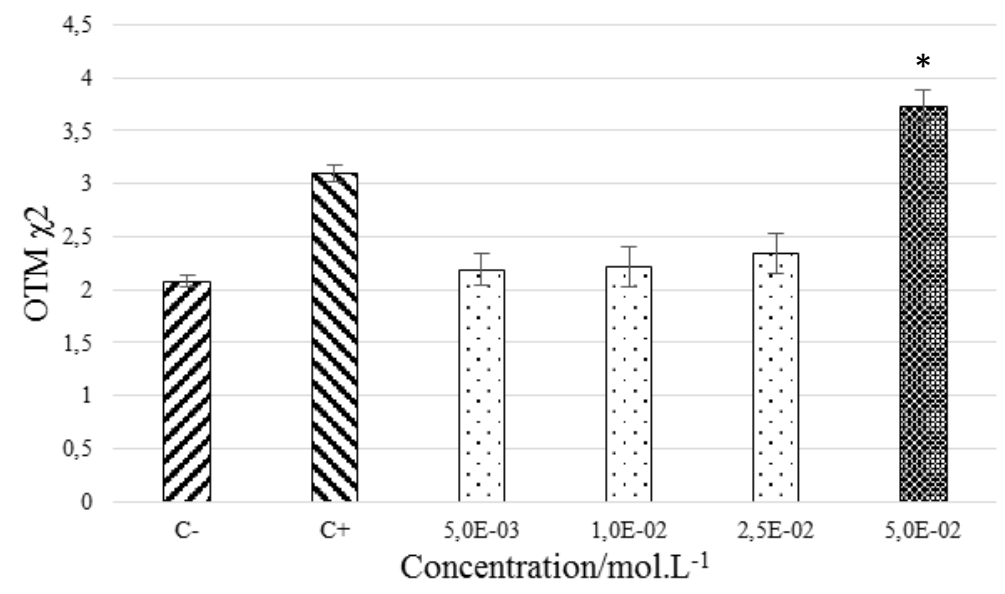

Figure 1: Nickel impact on DNA. The first bar is the positive control. Significant assay is represented by the dark bar with the star $(p<0.001)$ 


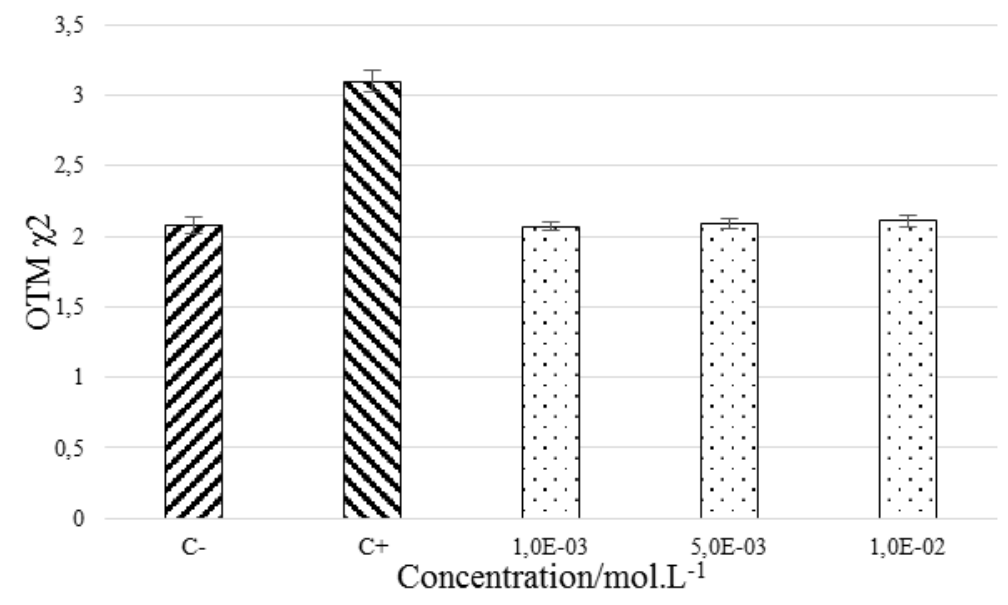

Figure 1: Aluminum impact on DNA. The first bar is the positive control. No significant result 


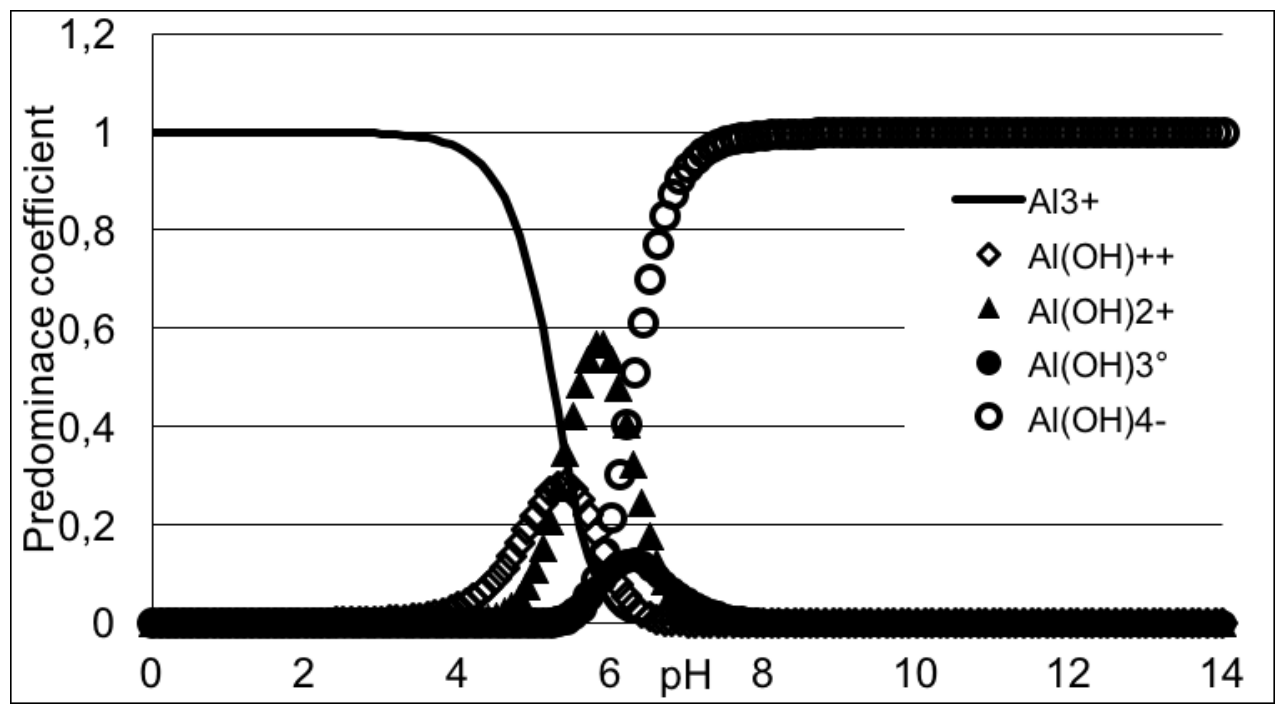

Figure 1: Species predominance diagram of aluminum in water at $\mathrm{NaCl}$ concentration $=0.150 \mathrm{~mol} . \mathrm{L}^{-1}$ 


$$
\text { K I L }
$$



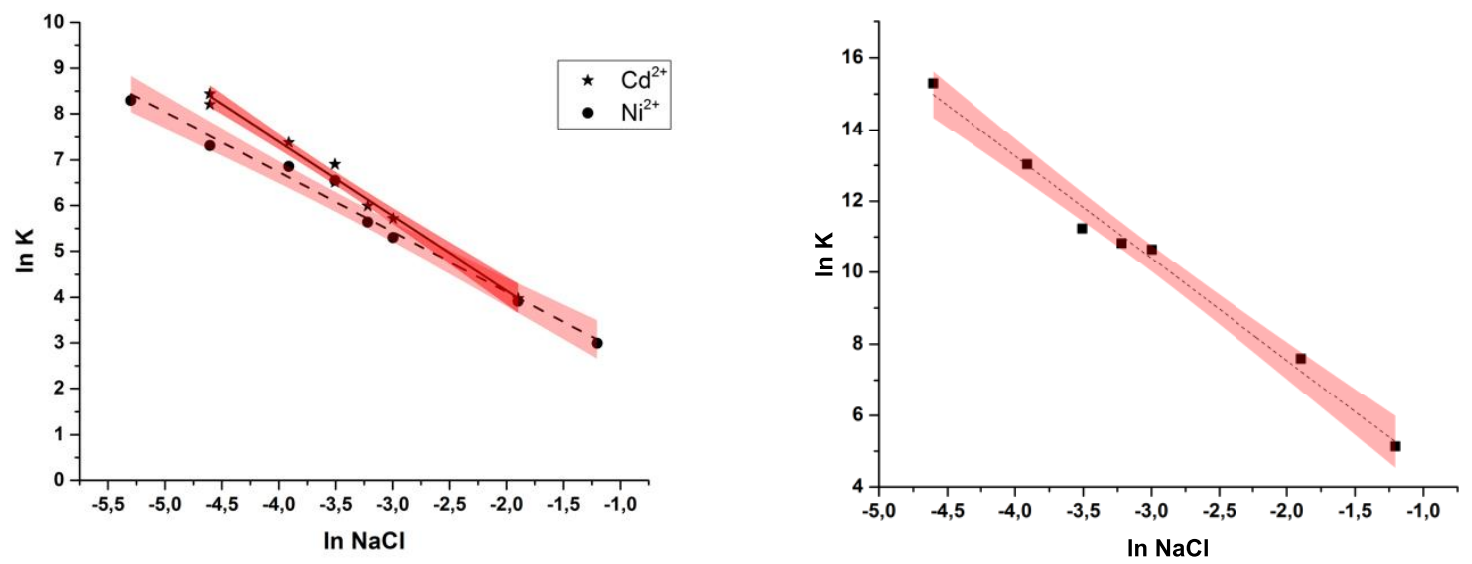

Figure 1: Dependence of the affinity constant on sodium chloride concentration. (a) Dashed and solid lines represent the linear fitting for $\mathrm{Cd}^{2+}$ and $\mathrm{Ni}^{2+}$. (b) Dashed and solid lines represent the linear fitting for $\mathrm{Al}^{3+}$. The shade bands around the linear fits represent the confidence interval of $95 \%$. 


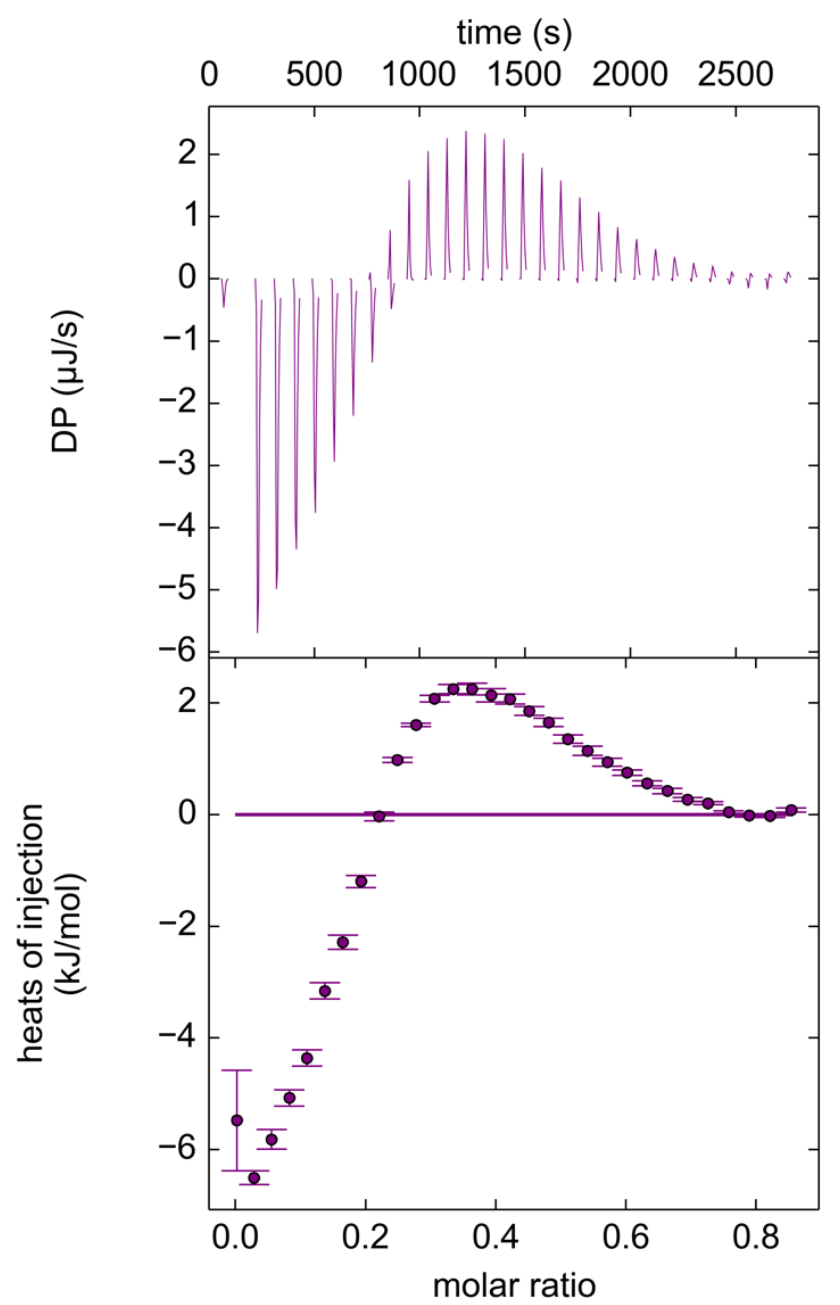

Figure 1: Isothermal titration curve of Cd2+ binding to DNA at $37^{\circ} \mathrm{C}$ in TRIS buffer at 5 mmol.L-1 with $\mathrm{NaCl}$ concentration lower than $5 \mathrm{mM}$. The upper curve shows the heat flow versus the time and the lower part shows the heat versus the Cd2+/DNA-P molar ratio [41]. 